Available online at http://iddtonline.info

REVIEW ARTICLE

\title{
A REVIEW ON "HOW EXACTLY DIURETIC DRUGS ARE WORKING IN OUR BODY"
}

\author{
*Mishra Snigdha, Sharma Satish Kumar' Yadav Jaya' Bhawna Kasana \\ Sunder Deep Pharmacy College, Ghaziabad, UP, India-201001 \\ *Corresponding Author's Email: snigdha2112@gmail.com, Mobile: 7838554347
}

\section{ABSTRACT}

Diuretics are among the most commonly used drugs. They act by diminishing sodium reabsorption at different sites in the nephron, thereby increasing urinary sodium and water losses. The ability to induce negative fluid balance has made diuretics useful in the treatment of a variety of conditions, particularly edematous states and hypertension. A review on physiology of kidney, nephron, urine formation, diuretic drugs with their classification and the mechanism of various diuretics are discussed here with neatly described schematic diagrams.
\end{abstract}

Key words Diuretics, Kidney, Nephron, Physiology of urine formation, Mechanism of action of various diuretic drugs.

\section{INTRODUCTION}

\section{Kidney}

The kidneys are reddish-brown, bean-shaped organs situated retroperitoneal on the posterior abdominal wall. There are two, one on each side of the spine. The asymmetry within the abdominal cavity caused by the liver typically results in the right kidney being slightly lower than the left, and left kidney being located slightly more medial than the right. The left kidney is approximately at the vertebral level T12 to L3, and the right slightly lower. Each adult kidney weighs between 125 and 170 grams in males and between 115 and 155 grams in females. ${ }^{1}$ The left kidney is typically slightly larger than the right kidney. ${ }^{2}$ Each kidney is about 4 or 5 inches long - about the size of a fist. The kidneys' participates in whole-body homeostasis, regulating acidbase balance, electrolyte concentrations, extracellular fluid volume, and regulation of blood pressure. Many of the kidney's functions are accomplished by relatively simple mechanisms of filtration, reabsorption, and secretion, which take place in the nephron. Filtration, which takes place at the renal corpuscle, is the process by which cells and large proteins are filtered from the blood to make an ultrafiltrate that eventually becomes urine. The kidney generates 180 liters of filtrate a day, while reabsorbing a large percentage, allowing for the generation of only approximately 2 liters of urine. Reabsorption is the transport of molecules from this ultrafiltrate and into the blood. Secretion is the reverse process, in which molecules are transported in the opposite direction, from the blood into the urine. All the blood in our bodies passes through the kidneys several times a day. The kidneys remove wastes, control the body's fluid balance, and regulate the balance of electrolytes. As the kidneys filter blood, they create urine, which collects in the kidneys' pelvis - funnelshaped structures that drain down tubes called ureters to the bladder. Each kidney contains around a million units called nephrons, each of which is a microscopic filter for blood. ${ }^{3}$

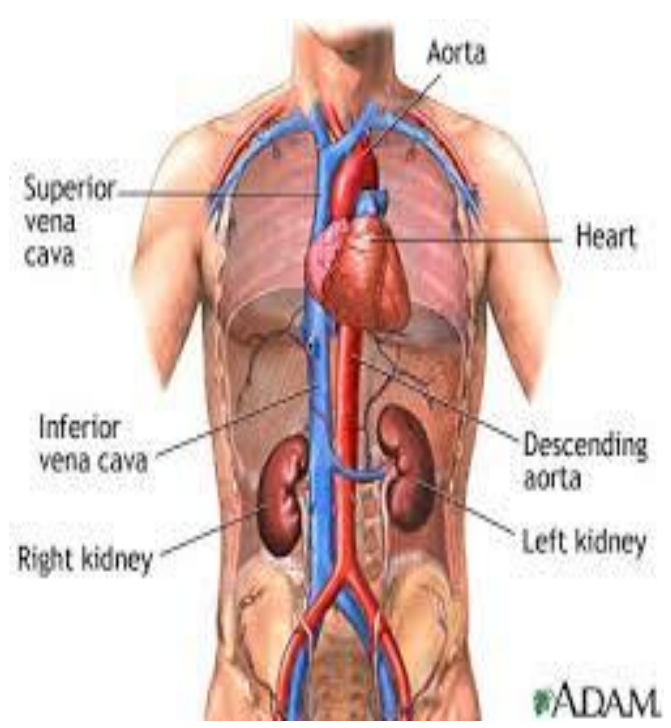

Figure 1: Location of kidney in human body

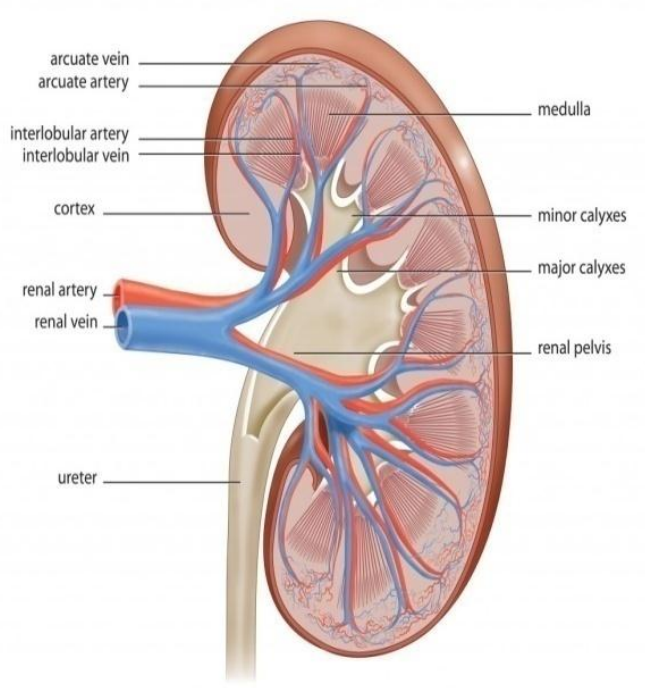

Figure 2: Anatomy of kidney 


\section{Nephron}

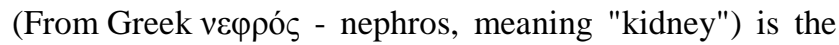
basic structural and functional unit of the kidney. Its chief function is to regulate the concentration of water and soluble substances like sodium salts by filtering the blood reabsorbing what is needed and excreting the rest as urine A nephron eliminates wastes from the body, regulates blood volume and blood pressure controls levels of electrolytes and metabolites, and regulates blood $\mathrm{pH}$. Its functions are vital to life and are regulated by the endocrine system by hormones such asantidiuretic hormone, aldosterone, and parathyroid hormone. ${ }^{4}$ In humans, a normal kidney contains 800,000 to 1.5 million nephrons. ${ }^{5}$

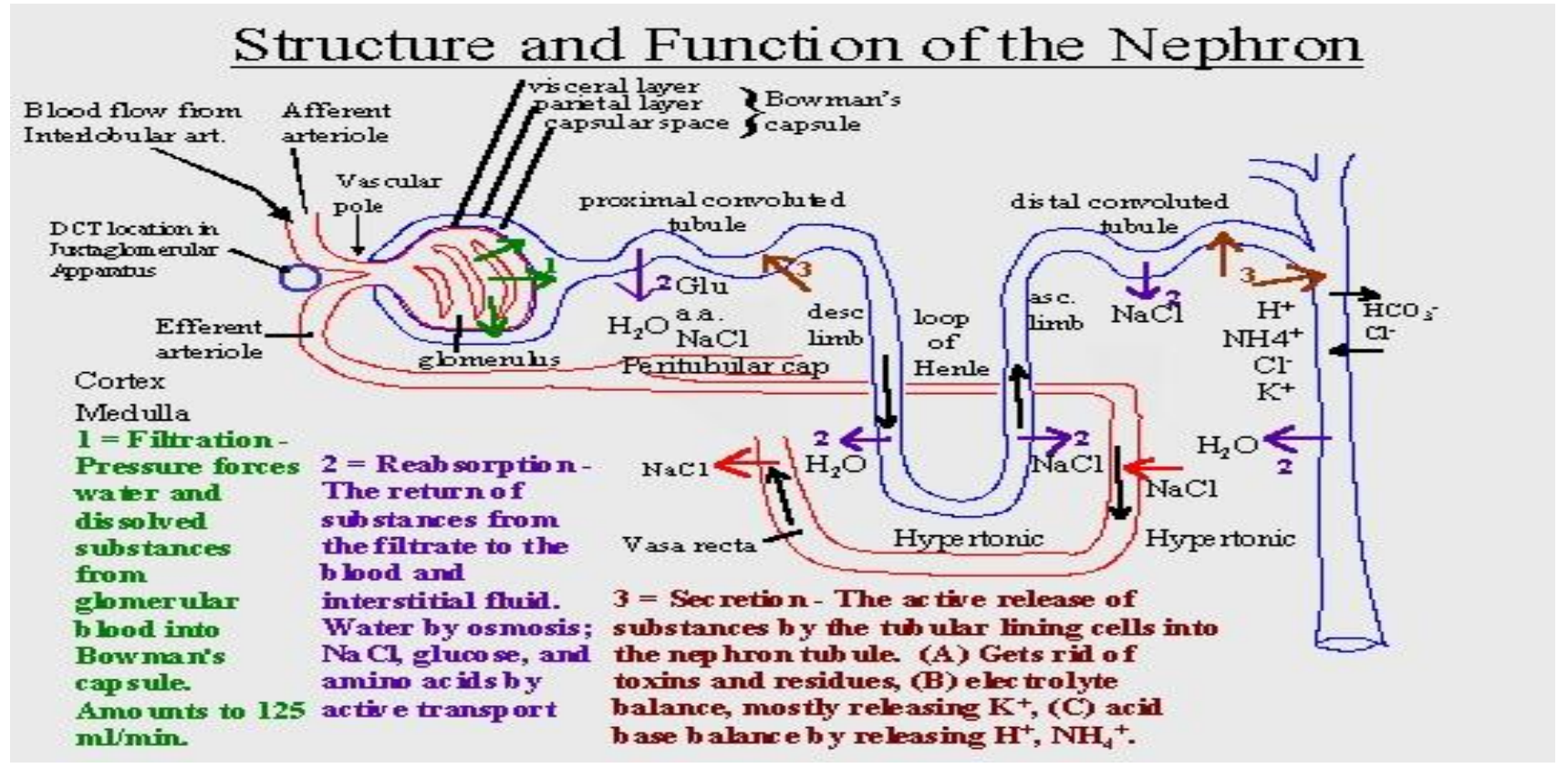

Figure 3: structure and function of nephron

\section{Renal Pharmacology}

Each nephron is composed of an initial filtering component (the "renal corpuscle") and a tubule specialized for reabsorption and secretion (the "renal tubule"). The renal corpuscle filters out solutes from the blood, delivering water and small solutes to the renal tubule for modification.

The glomerulus is a capillary tuft that receives its blood supply from an afferent arteriole of the renal circulation. The glomerular blood pressure provides the driving force for water and solutes to be filtered out of the blood and into the space made by Bowman's capsule. The remainder of the blood (only approximately $1 / 5$ of all plasma passing through the kidney is filtered through the glomerular wall into the Bowman's capsule) passes into the efferent arteriole. he Bowman's capsule, also called the glomerular capsule, surrounds the glomerulus. It is composed of a visceral inner layer formed by specialized cells called podocytes.

The renal tubule is the portion of the nephron containing the tubular fluid filtered through the glomerulus. ${ }^{6}$ After passing through the renal tubule, the filtrate continues to the collecting duct system, which is not part of the nephron. The components of the renal tubule are:

- Proximal convoluted tubule (lies in cortex and lined by simple cuboidal epithelium with brushed borders which help to increase the area of absorption greatly.)

- Loop of Henle (hair-pin like i.e. U-shaped and lies in medulla)

$>$ Descending limb of loop of Henle

$>$ Ascending limb of loop of Henle

- The ascending limb of loop of Henle is divided into 2 segments: Lower end of ascending limb is very thin and is lined by simple squamous epithelium. The distal portion of ascending limb is thick and is lined by simple cuboidal epithelium.

- Thin ascending limb of loop of Henle

- Thick ascending limb of loop of Henle (enters cortex and becomes DCT-distal convoluted tubule.)

- Distal convoluted tubule 


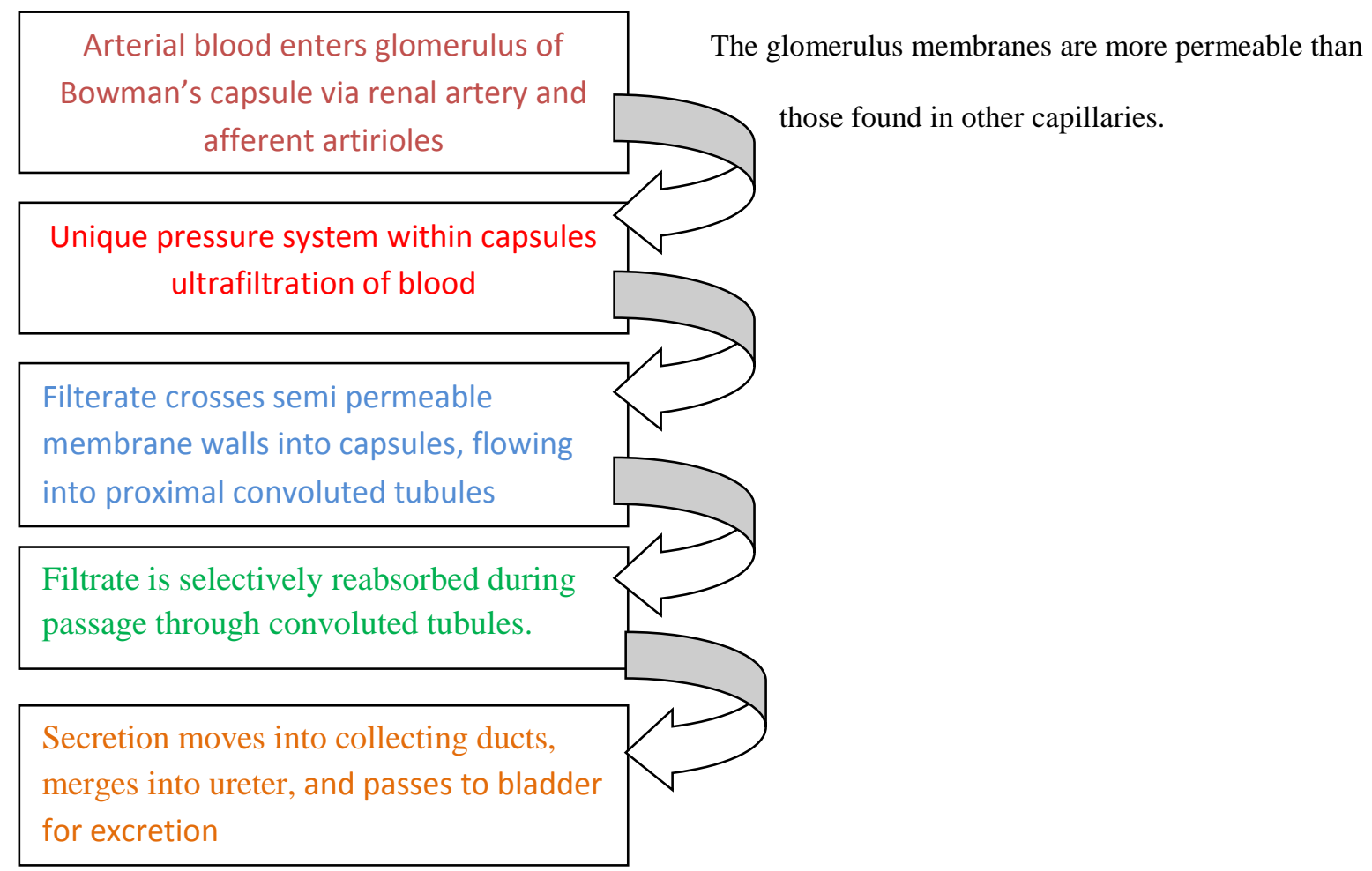

Fig.4 Schematic flow chart of urine production

Urine production In regards to urine production, the most important hormone is Antidiuretic hormone, or $\mathrm{ADH}$. $\mathrm{ADH}$ makes the collecting duct more permeable to water. Thus, secretion of $\mathrm{ADH}$ causes the retention of water in the body, and more concentrated urine. (ADH is usually secreted in response to environmental situations that require the retention of water.)

\section{Diuretics}

A diuretic will have opposite effect: decreases permeability of collecting tubule, so body loses lots of water (copious, dilute urine). Examples of diuretics: caffeine, alcohol etc. Diuretic agents are drugs that increase renal excretion of water and solutes (mainly sodium excretion). Major purposes of diuretic therapy are to decrease fluid volume of the body, and to adjust the water and electrolyte balance. Diuretics are often used in the management of pathological conditions such as edema (e.g. in congestive heart failure and certain renal diseases),

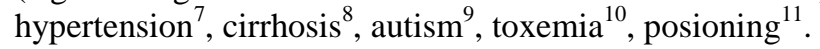

Most diuretics exert their effects by inhibiting tubular sodium and water reabsorption by epithelial cells lining the renal tubule system. Certain diuretics (such as carbonic anhydrase inhibitors, loop diuretics, thiazide-like diuretics and potassium-sparing diuretics) suppress sodium and water reabsorption by inhibiting the function of specific proteins that are responsible for (or participate in) the transportation of electrolytes across the epithelial membrane; osmotic diuretics inhibit water and sodium reabsorption by increasing intratubular osmotic pressure. Different types of diuretics may inhibit different transporters in different segments of the tubular system. ${ }^{7}$

Table 1: DTL descending thin limb, TAL Thick ascending limb

\begin{tabular}{|c|c|c|c|c|}
\hline \multicolumn{2}{|c|}{ Type } & Example & Site of action & Mechanism \\
\hline \multicolumn{2}{|c|}{$\begin{array}{l}\text { Carbonic anhydrase } \\
\text { inhibitors }\end{array}$} & Acetazolamide & Proximal tubule & $\begin{array}{l}\text { inhibition of Carbonic } \\
\text { anhydrase }\end{array}$ \\
\hline \multicolumn{2}{|l|}{ Osmotic } & Mannitol & Loop of Henle (DTL) & $\begin{array}{l}\text { Osmotic action Proximal } \\
\text { tubule }\end{array}$ \\
\hline \multicolumn{2}{|c|}{ Loop diuretics } & Furosemide & $\begin{array}{l}\text { Loop of Henle (TAL) } \\
\text { Proximal tubule }\end{array}$ & $\begin{array}{l}\text { inhibition of } \mathrm{Na}+-\mathrm{K}+-2 \mathrm{Cl} \\
\text { symport }\end{array}$ \\
\hline \multicolumn{2}{|l|}{ Thiazides } & Hydrochlorothiazide & Distal convoluted & $\begin{array}{l}\text { inhibition of } \mathrm{Na}+-\mathrm{Cl} \text { tubule } \\
\text { symport }\end{array}$ \\
\hline \multirow{2}{*}{$\begin{array}{l}\text { Potassium- } \\
\text { sparing } \\
\text { diuretics }\end{array}$} & $\begin{array}{l}\mathrm{Na}+\text { channel } \\
\text { inhibitor }\end{array}$ & Triamterene, Amilorides & Cortical collecting tubule & inhibition of $\mathrm{Na}+$ channels \\
\hline & $\begin{array}{l}\text { Aldosterone } \\
\text { antagonist }\end{array}$ & Spironolactone & Cortical collecting tubule & $\begin{array}{l}\text { inhibition of aldosteron } \\
\text { receptor }\end{array}$ \\
\hline
\end{tabular}


Carbonic anhydrase inhibitor: (acetazolamide) Acetazolamide acts by interfering with bicarbonate $\left(\mathrm{HCO}_{3}{ }^{-}\right.$ ) reabsorption in the kidneys, thereby reacidifying the blood - hence alkalyzing the urine. There is an enzyme called cabonic anhydrase which catalyzes the reaction reversibly. $\mathrm{CO}_{2}+\mathrm{H}_{2} \mathrm{O}<-{ }_{--}{ }_{--}>\mathrm{H}_{2} \mathrm{CO}_{3}<-->\mathrm{H}^{+}+\mathrm{HCO}_{3}^{-}$

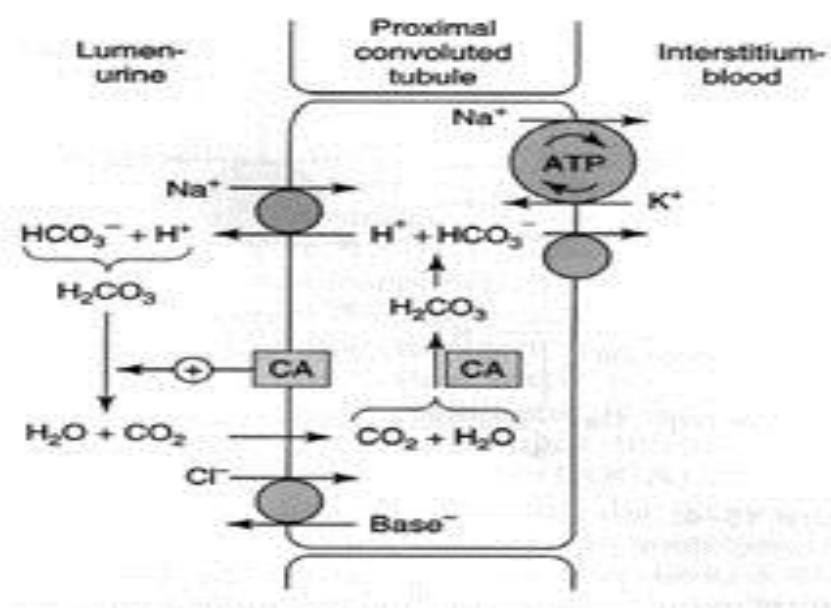

Fig. 5 Mechanism of action of acetazolamide

In the kidney tubules, locally secreted hydrogen ions normally combine with filtered bicarbonate $\left(\mathrm{HCO}_{3}{ }^{-}\right)$to form carbonic acid $\left(\mathrm{H}_{2} \mathrm{CO}_{3}\right)$. Carbonic acid in turn is normally acted upon by carbonic anhydrase, leading to formation of $\mathrm{CO}_{2}$. As $\mathrm{CO}_{2}$ rapidly leaves the tubules by diffusing across cell membranes, the above reaction normally runs shifted strongly to the left (i.e. reversed), and more bicarbonate can be continuously reabsorbed from the preurine. However, in the presence of acetazolamide, carbonic anhydrase is inhibited and carbonic acid levels build up. The inhibition of carbonic anhydrase in turn leads to a slowing of the reverse reaction and a decrease in the body's ability to reabsorb serum bicarbonate, resulting in urinary bicarbonate wasting. This leads to a decreased ability to exchange $\mathrm{Na}^{+}$for $\mathrm{H}^{+}$in the presence of acetazolamide (in proximal convoluted tubules of kidney) resulting in a mild diuresis ${ }^{12}$.

In short we can say inhibition of $\mathrm{H}^{+}$secretion and reabsorption of $\mathrm{HCO}_{3}{ }^{-}$takes place which results in reduction of $\mathrm{Na}^{+}$reabsorption in proximal tubules by inhibiting the enzyme carbonic anhydrase ${ }^{13}$.

Osmotic diuretic Osmotic diuretics are freely filterable but not reabsorbed and prevent $\mathrm{H} 2 \mathrm{O}$ reabsorption in the proximal tubule. Osmotic diuretics also extract $\mathrm{H} 2 \mathrm{O}$ from systemic body compartments. This expands extracellular fluid volume and increases renal blood flow. This increase in blood flow removes $\mathrm{NaCl}$ and urea from the renal medulla ${ }^{14}$. Loss of these solutes decreases the medullary toxicity and hence the ability to generate a concentrated urine. Compounds such as mannitol are filtered in the glomerulus, but cannot be reabsorbed. Their presence leads to an increase in the osmolarity of the filtrate. To maintain osmotic balance, water is retained in the urine ${ }^{15}$.

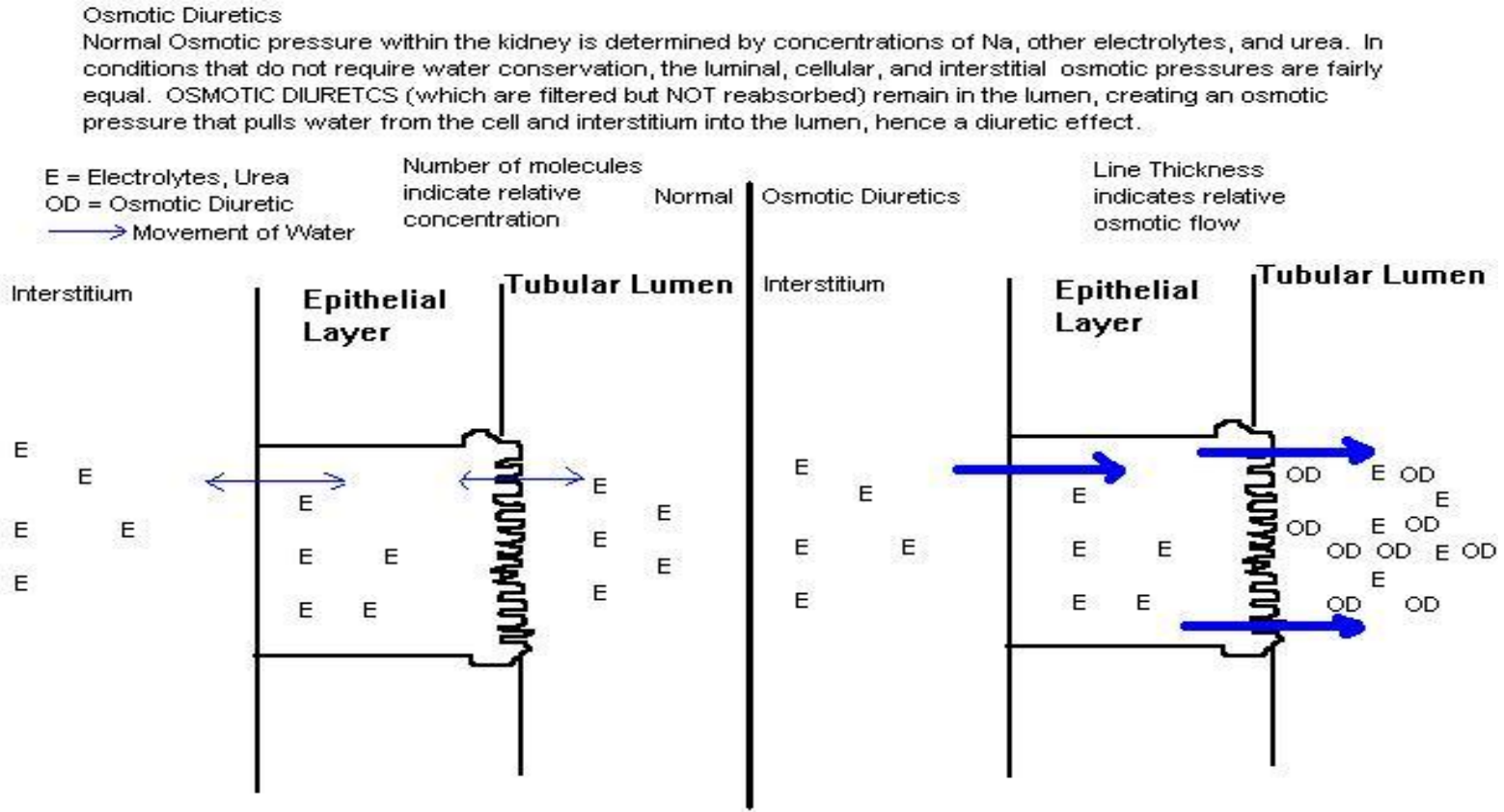

Figure 6: Showing mechanism of action of osmotic diuretic

Loop diuretics: These diuretics act on the ascending loop of Henle in the kidney. Loop diuretics act on the $\mathrm{Na}^{+}-\mathrm{K}^{+}$$2 \mathrm{Cl}^{-}$symporter (cotransporter) in the thick ascending limb of the loop of Henle to inhibit sodium and chloride reabsorption. This is achieved by competing for the $\mathrm{Cl}^{-}$ binding site. 


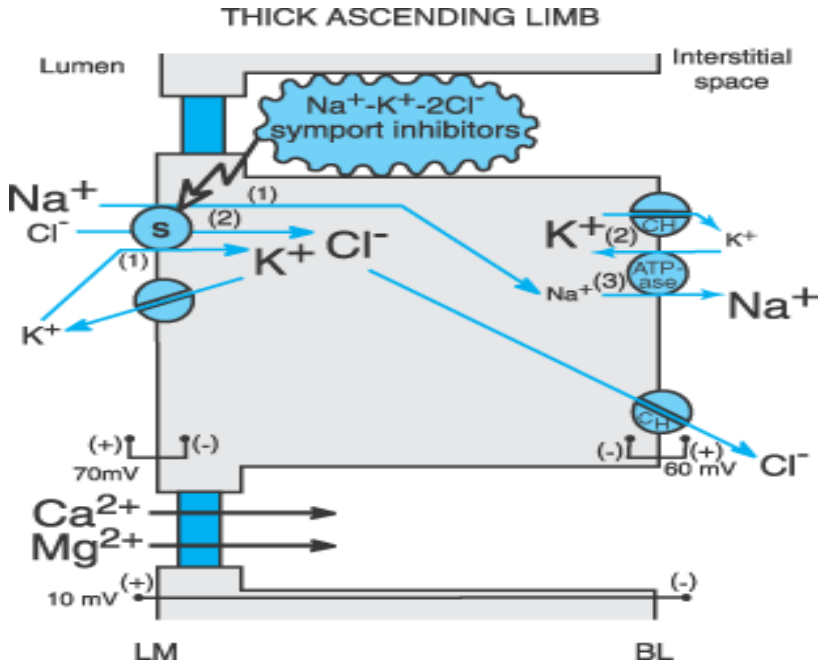

Figure 7: Mechanism of action of loop diuretics

Therefore, reabsorption of these ions is decreased. The loop diuretics are the most efficacious of the diuretic drugs, because the ascending limb accounts for the reabsorption of 25 to 30 percent of filtered $\mathrm{NaCl}$, and downstream sites are not able to compensate for this increased $\mathrm{Na}^{+}$load.

Changes in the composition of the urine induced by loop diuretics .Loop diuretics increase the $\mathrm{Ca}^{2+}$ content of urine, whereas thiazide diuretics decrease the $\mathrm{Ca}^{2+}$ concentration of the urine. In patients with normal serum $\mathrm{Ca}^{2+}$ concentrations, hypocalcemia does not result, because $\mathrm{Ca}^{2+}$ is reabsorbed in the distal convoluted tubule. However, hypomagnesemia can occur due to loss of $\mathrm{Mg}^{2+12}$ The reabsorption of calcium in the loop of Henle is primarily passive, being driven by the gradient created by $\mathrm{NaCl}$ transport and occurring through the paracellular pathway $^{16,17}$. As a result, inhibiting the reabsorption of $\mathrm{NaCl}$ leads to a parallel reduction in that of calcium, thereby increasing calcium excretion. This effect is clinically important, because enhancing urinary calcium losses with saline and a loop diuretic is a mainstay of therapy in patients with hypercalcemia ${ }^{18}$.

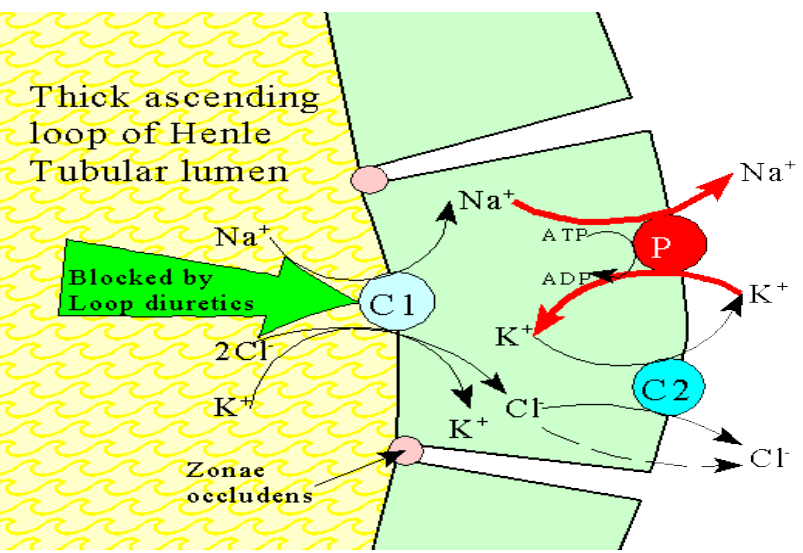

Figure 8: Mechanism of action of thiazide diuretics

Thiazide: The thiazide diuretics primarily inhibit sodium transport in the distal tubule ${ }^{19,20}$, the connecting segment at the end of the distal tubule ${ }^{21}$, and possibly the early cortical collecting tubule (although this finding is controversial) ${ }^{22}$. Thiazide-sensitive sodium entry in the distal nephron is mediated by neutral $\mathrm{Na}-\mathrm{Cl}$ cotransport. Both a Na-Cl cotransporter and, to a lesser degree, parallel $\mathrm{Na}-\mathrm{H}$ and $\mathrm{Cl}-\mathrm{HCO} 3$ exchangers are responsible for $\mathrm{NaCl}$ reabsorption at these $\operatorname{sites}^{23}$. The thiazides inhibit $\mathrm{NaCl}$ reabsorption in these segments by competing for the chloride site on the transporters ${ }^{24}$. Some of these drugs (such as chlorothiazide) also modestly impair sodium transport in the proximal tubule, due in part to partial inhibition of carbonic anhydrase $e^{25}$.

Potasium sparing diuretics: The three potassium-sparing diuretics, amiloride, spironolactone, and triamterene, act in the principal cells in the cortical collecting tubule (and possibly in the papillary or inner medullary collecting duct ${ }^{19}$ Sodium entry in these segments occurs through aldosterone-sensitive sodium channels, rather than being carrier-mediated $^{26,27}$. he reabsorption of cationic sodium without an anion creates a lumen-negative electrical gradient that then favors the secretion of potassium (through selective potassium channels) and hydrogen ions. Thus, inhibition of sodium reabsorption at this site can lead to hyperkalemia and metabolic acidosis due to the concurrent reductions in potassium and hydrogen ion excretion $^{19,20}$

Amiloride, triamterene, and spironolactone decrease the number of open sodium channels; the first two are cations and act directly on the channels and spironolactone competitively inhibits the effect of aldosterone ${ }^{28,} 29$. Spironolactone also may inhibit the effect of aldosterone in the distal tubule, diminishing the number of $\mathrm{Na}-\mathrm{Cl}$ cotransporters $^{30}$. The potassium-sparing diuretics have relatively weak natriuretic activity, leading to the maximum excretion of only 1 to 2 percent of the filtered sodium $^{19}$ Thus, they are primarily used in combination with a loop or thiazide diuretic, either to diminish the degree of potassium loss or to increase the net diuresis in patients with refractory edema.

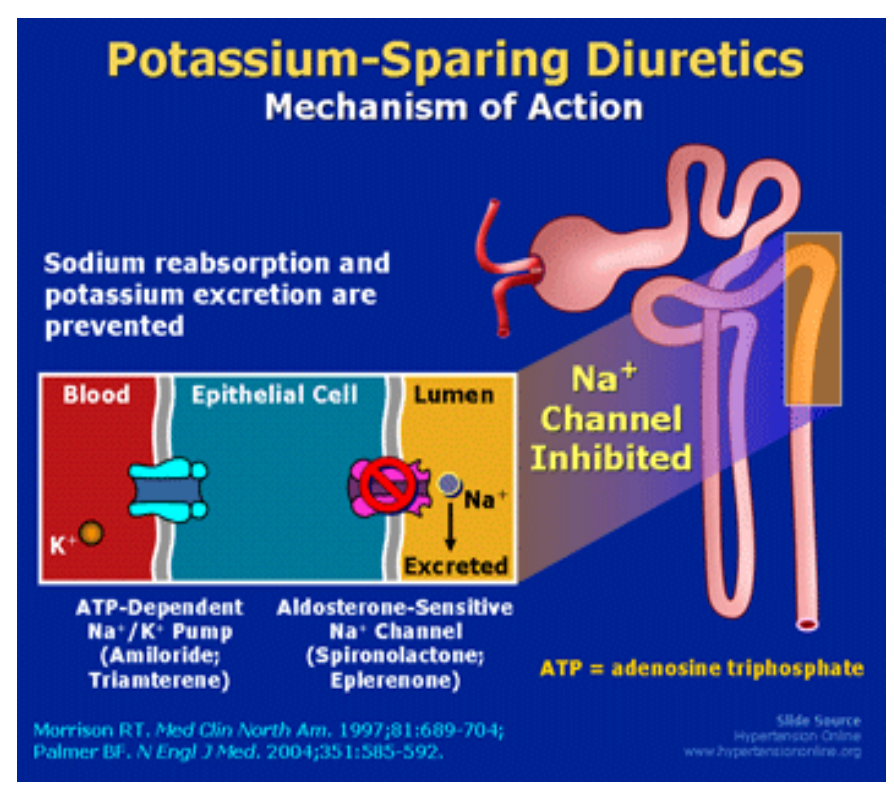

Figure 9: Mechanism of action of potassium sparing diuretics 


\section{REFERENCES}

1. Walter F., PhD. Boron (2004). Medical Physiology: A Cellular and Molecular Approach. Elsevier/Saunders.ISBN 1-4160-23283.

2. Glodny B, Unterholzner V, Taferner B, et al. (2009). "Normal kidney size and its influencing factors - a 64-slice MDCT study of 1.040 asymptomatic patients". BMC Urology 9:

19. doi:10.1186/1471-2490-9-19

3. Clapp, WL. Renal Anatomy. In: Zhou XJ, Laszik Z, Nadasdy T, D'Agati VD, Silva FG, eds. Silva's Diagnostic Renal Pathology. New York, NY: Cambridge University Press; 2009.

4. Maton, Anthea; Jean Hopkins, Charles William McLaughlin, Susan Johnson, Maryanna Quon Warner, David LaHart, Jill D. Wright (1993). Human Biology and Health. Englewood Cliffs, New Jersey, USA: Prentice Hall. ISBN 0-13-981176-1.

5. Guyton, Arthur C.; Hall, John E. (2006). Textbook of Medical Physiology. Philadelphia: Elsevier Saunders. p. 310. ISBN 07216-0240-1.

6. Ecology \& Evolutionary Biology, University of Colorado at Boulder. The kidney tubule: urineproduction. URL: http://www.colorado.edu/eeb/web_resources/cartoons/neph rex1.html

7. Xiaoping Du, MD, PhD., Department of Pharmacology Phone: (312) 355 0237; Email: xdu@uic.edu

8. Elaine Yeung, MD, Florence S. Wong, MD.The Management of Cirrhotic, FRCP $(\mathrm{C})$ DisclosuresMedscape General Medicine. 2002;4 (4)

9. Lemonnier E, Ben Ari Y. The diuretic bumetanide decreases autistic behaviour in five infants treated during 3 months with no side effect 2010; 99 (12):1885-8

10. Smith GN, Walker M, Tessier JL, Millar KG. Increased incidence of preeclampsia in women conceiving by intrauterine insemination with donor versus partner sperm for treatment of primary infertility. Am J Obstet Gynecol 1997; 177:455-8.

11. K. Prowse, M. Pain, A. D. Marston and G. Cumming, The treatment of salicylate poisoning using Mannitol and forced alkaline diuresis, Clinical Science (1970) 38, 327-337.

12. Lippincott's Illustrated Reviews: Pharmacology, 4th edition page 428.

13. Guyton and Hall Text book of Medical Physiology

14. M.T, Piascik, The Pharmacodynamics of diuretic drugs PHA 824 http://connection.lww.com/products/craig/documents/Ch21.pdf
15. Mutschler, Ernst (1995). Drug actions: basic principles and therapeutic aspects. Stuttgart, German: Medpharm Scientific Pub. p. 460. ISBN 0-8493-7774-9.

16. Bronner, F. Renal calcium transport: Mechanisms and regulation - An overview. Am J Physiol 1989; 257:F707.

17. Friedman, PA. Basal and hormone-activated calcium absorption in mouse renal thick ascending limbs. Am J Physiol 1988; 254:F62.

18. Bilezikian, JP. Drug therapy: Management of acute hypercalcemia. N Engl J Med 1992; 326:1196.

19. Rose, BD. Diuretics. Kidney Int 1991; 39:336.

20. Hropot, M, Fowler, N, Karlmark, B, Giebisch, G. Tubular action of diuretics: Distal effects on electrolyte transport and acidification. Kidney Int 1985; 28:477.

21. Shimizu, T, Yoshitomi, K, Nakamura, M, Imai, M. Site and mechanism of action of trichlormethazide in rabbit distal nephron segments perfused in vitro. J Clin Invest 1988; 82:721.

22. Terada, Y, Knepper, MA. Thiazide-sensitive $\mathrm{NaCl}$ absorption in rat cortical collecting duct. Am J Physiol 1990; 259:F519.

23. Stanton, BA. Cellular actions of thiazide diuretics in the distal tubule. J Am Soc Nephrol 1990; 1:836.

24. Tran, JM, Farrell, MA, Fanestil, DD. Effect of ions on binding of the thiazide-type diuretic metolazone to the kidney membrane. Am J Physiol 1990; 258:F908.

25. Boer, WH, Koomans, HA, Dorhout Mees, EJ. Acute effects of the thiazides, with and without carbonic anhydrase inhibiting activity, on lithium and free water clearance in man. Clin Sci 1989; 76:539.

26. Frindt, G, Sackin, H, Palmer, LG. Whole-cell currents in rat cortical collecting tubule: Low-Na diet increases amiloridesensitive conductance. Am J Physiol 1990; 258:F562.

27. Sansom, S, Muto, S, Giebisch, G. Na-dependent effects of DOCA on cellular transport properties of CCDs from ADX rabbits. Am J Physiol 1987; 253:F753.

28. Kleyman, TR, Cragoe, EJ Jr. The mechanism of action of amiloride. SeminNephrol 1988; 8:242.

29. Horisberger, JD, Giebisch, G. Potassium-sparing diuretics. Ren Physiol 1987; 10:198.

30. Abdallah, JG, Schrier, RW, Edelstein, C, et al. Loop diuretic infusion increases thiazide-sensitive $\mathrm{Na}(+) / \mathrm{Cl}(-)$-cotransporter abundance: role of aldosterone. J Am Soc Nephrol 2001; $12: 1335$ 